\title{
Pengembangan Electronic Wordless Picture Book untuk Mengenalkan Social Justice pada Anak Usia 4-6 Tahun
}

\author{
Eka Oktavianingsih ${ }^{1 凶}$, Siti Fadjryana Fitroh $^{1}$ \\ Pendidikan Guru Pendidikan Anak Usia Dini, Universitas Trunojoyo Madura, Indonesia(1) \\ DOI: $10.31004 /$ obsesi.v6i4.1992
}

\begin{abstract}
Abstrak
Nilai social justice sangat penting dikenalkan sejak dini untuk menghindari berbagai macam persoalan perbedaan yang terjadi seperti bullying, ketidakadilan gender, dan intoleransi. Penelitian ini bertujuan untuk (1) mengembangkan electronic wordless picture book untuk mengenalkan social justice pada anak usia 4 sampai 6 tahun, dan (2) menguji kelayakan electronic wordless picture book ditinjau dari aspek validitas dan efektivitas. Penelitian ini merupakan penelitian dan pengembangan (research and development) dengan model ADDIE (Analysis, Design, Development, Implementation, dan Evaluation). Sebanyak 30 anak usia 4 sampai 6 tahun di RA Muslimat NU Darun Najah ditentukan sebagai subjek penelitian menggunakan teknik sampling jenuh. Kelayakan electronic wordless picture book dilihat dari aspek validitas diperoleh melalui penilaian ahli media dan ahli materi, sedangkan aspek efektivitas diperoleh melalui observasi terhadap kemampuan social justice pada anak usia 4 sampai 6 tahun. Hasil penelitian menunjukkan bahwa electronic wordless picture book telah layak ditinjau dari aspek validitas materi dengan kategori sangat baik, aspek validitas media dengan kategori sangat baik, serta aspek efektivitas dengan kategori baik.
\end{abstract}

Kata Kunci: social justice; anak; wordless picture book; electronic.

\begin{abstract}
The value of social justice is very important to be introduced from an early age to avoid various kinds of differences that occur such as bullying, gender injustice, and intolerance. This study aims to (1) develop an electronic wordless picture book to introduce social justice to children aged 4 to 6 years, and (2) test the feasibility of an electronic wordless picture book in terms of validity and effectiveness. This study is research and development with the ADDIE model (Analysis, Design, Development, Implementation, and Evaluation). A total of 30 children aged 4 to 6 years at RA Muslimat NU Darun Najah were determined as participants using a saturated sampling technique. The feasibility of the electronic wordless picture book seen from the aspect of validity was obtained through the assessment of media experts and material experts, while the effectiveness aspect was obtained through observation of the ability of social justice in children aged 4 to 6 years. The results showed that the electronic wordless picture book was worthy of review from the material validity aspect with very good, media validity aspect with very good, and the effectiveness aspect with good.
\end{abstract}

Keywords: social justice; children; wordless picture book; electronic.

Copyright (c) 2022 Eka Oktavianingsih, Siti Fadjryana Fitroh

$\triangle$ Corresponding author:

Email Address : eka.oktavianingsih@trunojoyo.ac.id (Madura, Indonesia)

Received 23 August 2021, Accepted 13 December 2021, Published 20 January 2022

Jurnal Obsesi : Jurnal Pendidikan Anak Usia Dini, 6(3), 2022 | 2495 


\section{PENDAHULUAN}

Permasalahan terkait dengan social justice di bidang pendidikan termasuk Pendidikan Anak Usia Dini misalnya bullying, ketidakadilan gender, dan intoleransi saat ini kian marak. Permasalahan tersebut timbul salah satunya karena adanya perbedaan seperti agama, ras, warna kulit, maupun status sosial ekonomi. Selanjutnya, Young, (2011) menyatakan bahwa masih ada lima jenis penindasan yang terjadi karena minimnya social justice dalam lingkungan pendidikan, termasuk di PAUD, diantaranya: eksploitasi, marginalisasi, ketidakberdayaan, imperialisme budaya, dan kekerasan. Salah satu dan yang paling sering terjadi dalam dunia pendidikan adalah jenis kekerasan simbolik yang dialami anak karena latar belakang ekonominya, sehingga kebebasan berpikir dan berpendapat anak tidak lagi diperhatikan.

Data menunjukkan tentang jumlah kasus bullying saat ini bentuknya bullying online. KPAI (Komisi Perlindungan Anak Indonesia) mencatat kenaikan yang signifikan dalam kurun waktu 9 tahun perundungan kekerasan pada anak sejak tahun 2011 sampai 2019 yakni mencapai 37.381. untuk kasus bullying baik di pendidikan maupun media social angkanya mencapai 2.473 dan terus meningkat (www.kpai.go.id). Fenomena ini seperti gunung es, yang mana peristiwa ini disebabkan beberapa faktor. Adapun faktor-faktor terjadinya bullying antara lain: faktor keluarga, faktor sekolah, faktor teman sebaya, faktor sosial ekonomi, dan faktor media (Zakiyah, 2017). Kondisi sosial ekonomi seperti kemiskinan dapat memicu individu untuk berbuat apa saja demi memenuhi kebutuhan hidupnya, misalnya melakukan pemalakan terhadap temannya. Menurut Fithriyana (2017) dalam penelitiannya tentang hubungan bullying dengan lingkungan social ekonomi menyatakan bahwa bullying biasanya dilakukan siswa yang berbadan lebih besar dari teman sekelasnya dan juga yang ekonomi keluarganya menengah ke atas. Ras, etnik, kelas dan gender adalah kategori social yang sangat menentukan jalan hidupnya seseorang dan partisipasinya dalam musyarakat dan ekonomi. Masih banyak yang mengalami diskriminasi berdasarkan gender dalam bentuk kesenjangan dan perbedaan tingkatan (https://www.kemenpppa.go.id). Seperti yang sudah dijelaskan sebelumnya, bahwa perbedaan status sosial ekonomi anak di sekolah dapat menimbulkan permasalahan seperti ketidakadilan gender dan masalah bullying.

Praktik-praktik ketidakadilan gender seringkali tanpa sadar dilakukan oleh guru ketika pembelajaran di kelas. Sebagai contoh, terkadang guru juga membedakan peran untuk anak laki-laki dan anak perempuan (Giraldo, 2008). Anak laki-laki diberikan media bermain peran dengan peran yang maskulin misalnya, menjadi polisi dengan sosok yang tegas, gagah dan berani, sedangkan anak perempuan biasanya diminta memerankan sosok yang feminin, lemah lembut dan baik hati. Selanjutnya, salah satu contoh perilaku bullying disebutkan oleh penelitian oleh Putri (2016) di TK X di Surabaya, dimana korban selalu menjadi bahan ejekan oleh teman-teman sebayanya dengan sebutan cewek dekil, hitam, dan tangannya asin. Tindakan bullying sendiri merujuk pada tindakan agresi yang dilakukan secara berulang oleh satu atau lebih anak yang diarahkan terhadap seorang korban yang seringkali terlihat lemah atau terisolasi sehingga lebih rentan.

Selain karena kondisi heterogenitas yang ada di dalam sebuah lembaga pendidikan, sebab lain dari berbagai masalah terkait social justice dikarenakan pengenalan nilai-nilai social justice yang masih jarang dilakukan. Salah satu penyebabnya adalah persepsi guru dan orangtua yang menganggap bahwa nilai social justice masih terlalu dini diajarkan pada anak. Hal ini didukung oleh penelitian yang dilakukan oleh Solehuddin (2017) yang menunjukkan bahwa sebagian besar guru Taman Kanak-kanak di Jawa Barat merasa kesulitan dalam memasukkan nilai social justice pada pembelajaran. Di sisi lain, tekanan orangtua dan masyarakat terhadap kemampuan kognitif anak juga menjadi salah satu faktor nilai social justice tidak begitu penting untuk diajarkan. Memperkenalkan nilai social justice pada anak usia dini bermanfaat agar anak dapat menghargai diri sendiri dan orang lain, serta dapat mengakui perbedaan dan keberagaman sehingga tercipta solidaritas dan persatuan (Hawkins, 2006). Selain itu, juga akan mengurangi ketidakadilan hak individu yang disebabkan karena perbedaan ras, suku, agama, ekonomi, dan lain sebagainya. 
Seperti yang sudah diungkapkan pada penelitian sebelumnya oleh Burman (2017) bahwa kurikulum PAUD saat ini masih menganggap bahwa mengajarkan social justice masih terlalu kompleks untuk anak-anak. Oleh sebab itu, dalam mengenalkan social justice perlu dilakukan secara hati-hati, karena anak usia dini masih berada pada tahapan pra operasional konkrit (Santrock, 2014). Penyampaian social justice kepada anak perlu dilakukan secara sederhana dan menyenangkan salah satunya melalui kegiatan bercerita. Isik (2016) menyebutkan bahwa kegiatan bercerita selain bermanfaat untuk kemajuan perkembangan bahasa anak, tetapi juga dapat meningkatkan kesejahteraan psikologis serta perkembangan kognitif anak. Pembelajaran meniru serta menentukan perilaku baik dan buruk dalam sebuah cerita juga akan membantu anak-anak dalam mengembangkan kepribadiannya.

Penelitian terdahulu oleh Darihastining (2021) menjelaskan bahwa salah metode dalam penyampaian pesan moral yaitu dengan media audio visual berbasis kearifan budaya lokal. Selain itu, penelitian dari Purnamasari (2019) juga menyebutkan bahwa salah satu media pembelajaran untuk meningkatkan karakter moral khususnya toleransi yaitu dengan media bigbook berbasis cerita rakyat. Selain berbentuk buku. untuk menyampaikan pesanpesan moral yang ada di dalam sebuah cerita, dibutuhkan sebuah media yang berfungsi untuk membuat konsep cerita yang abstrak menjadi lebih konkrit bagi anak, yaitu electronic wordless picture book. Wordless picture book merupakan salah satu jenis buku cerita bergambar yang minim kata atau tanpa kata sehingga pembaca akan menggunakan ilustrasi dan gambar untuk menciptakan makna di luar teks tertulis (Ciecierski, 2017). Selain dapat digunakan untuk meningkatkan kemampuan anak dalam menghubungkan literasi visual (belajar menafsirkan gambar), buku ini juga dapat digunakan untuk pembelajaran moral maupun harapan kelompok sosial (literasi budaya) (Jalongo, 2002).

Pada pengembangannya, wordless picture book dapat disajikan dalam bentuk elektronik bukan cetak yaitu electronic wordless picture book. Pertimbangan ini diambil peneliti karena buku elektronik dapat menarik minat anak dalam membaca sehingga nilai-nilai yang disampaikan dalam cerita tersebut akan mampu mengurangi perilaku negatifnya (Ciampa, 2012). Ketertarikan anak terhadap buku elektronik dikarenakan penggunaan berbagai elemen media seperti teks, gambar, dan warna. Alur cerita yang sederhana dan nilai-nilai karakter yang akan disampaikan melalui cerita dalam buku elektronik juga akan memudahkan anak untuk memahami isi cerita yang disampaikan. Selain itu, buku elektronik juga bersifat praktis untuk dibawa kemana saja (Evans, 2017). Penelitian mengenai wordless picture book sebelumnya telah banyak dilakukan salah satunya dalam mengembangkan karakter dan memudahkan dalam menyampaikan pesan moral kepada anak (Nurhasanah, 2019). Selanjutnya, gagasan mengenai picture book baik berupa fiksi, non fiksi, dan puisi dengan tema peace dan social justice sebelumnya telah dilakukan oleh (Seidel, 2011). Namun dari beberapa studi sebelumnya tersebut, untuk konten social justice untuk anak usia dini dalam cerita bergambar belum dijelaskan secara rinci tema-temanya dan bentuknya masih dalam versi cetak, bukan elektronik.

Berdasarkan penjelasan di atas, dapat dilihat bahwa belum ada yang mengkaji mengenai pengembangan wordless picture book berbentuk elektronik dalam mengenalkan social justice pada anak usia dini. Oleh karena itu, penelitian ini bertujuan untuk mengembangkan electronic wordless picture book dalam mengenalkan social justice pada anak usia dini. Adapun konten tema untuk electronic wordless picture book dalam mengenalkan social justice untuk anak usia dini mencakup gender equality dan anti bullying.

\section{METODOLOGI}

Penelitian tentang pengembangan Electronic Wordless Picture Book yang berfokus pada pengenalan social justice anak menggunakan metode penelitian dan pengembangan (research and development/ $R n D$ ). Penelitian pengembangan ini menggunakan model ADDIE yang mencakup lima langkah diantaranya: Analysis (menganalisis), Design (merancang), 
Development (mengembangkan), Implementation (mengimplementasi), dan Evaluation (mengevaluasi)).

Tahap Analysis bertujuan untuk menganalisis masalah yang ditemukan, fasilitas yang familiar digunakan anak, serta ketersediaan sarana dan prasarana pendukung proses belajar anak. Subjek yang terlibat adalah anak usia dini dan guru di RA NU Muslimat Darun Najah Kamal. Tahap Design bertujuan untuk merancang Electronic Wordless Picture Book yang berfokus pada pengenalan social justice, meliputi narasi cerita, referensi, pembuatan garis-garis besar, dan story board. Tahap Development dilakukan dengan mengembangkan produk sesuai dengan rancangan yang sudah dibahas sebelumnya. Setelah produk selesai kemudian akan divalidasi oleh dua dosen ahli (ahli materi dan media), dan dilakukan revisi sesuai arahan ahli. Tahap Implementation yang telah dikembangkan di dalam suatu proses pembelajaran dengan melibatkan sebanyak 30 anak usia 4-6 tahun di RA Nu Muslimat Darun Najah. Pada proses ini akan digunakan lembar observasi social justice anak setelah belajar dengan menggunakan produk yang dikembangkan. Tahap Evaluation merupakan hasil proses validasi ahli, angket respon guru, dan lembar observasi siswa yang didapatkan dari proses pengembangan sampai implementasi akan digunakan untuk menyimpulkan apakah produk yang dikembangkan valid, praktis dan efektif.

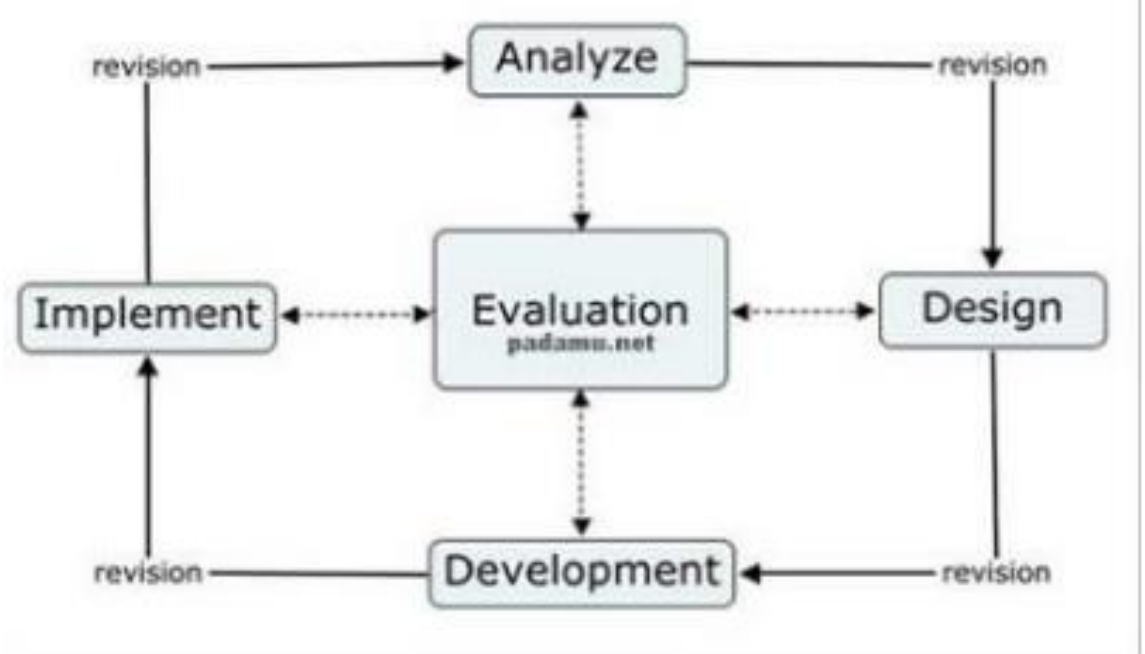

Gambar 1. Tahapan Model ADDIE

Adapun produk yang dikembangkan adalah Electronic Wordless Picture Book dengan dua tema yaitu gender equality dan anti bullying. Penelitian dilakukan di Panti Sosial Darunnajah, Kecamatan Kamal, Kabupaten Bangkalan. Pertimbangan pemilihan lokasi penelitian tersebut karena berpotensi untuk diteliti yakni memiliki anak didik yang memiliki beragam latar belakang sosial dan ekonomi. Adapun jumlah sampel yang akan dilibatkan dalam penelitian ini adalah sebanyak 30 anak usia 4-6 tahun di RA Muslimat Darun Najah, Kamal. Adapun teknik pengambilan sampel dengan menggunakan teknik sampling jenuh, dimana semua anggota populasi digunakan sebagai sampel penelitian.

Teknik pengumpulan data pada penelitian ini menggunakan teknik wawancara, kuesioner, dan observasi/pengamatan. Wawancara digunakan untuk menemukan permasalahan yang ada secara lebih terbuka. Angket/kuesioner tertutup digunakan untuk proses validasi produk oleh ahli materi maupun media. Observasi digunakan untuk mengetahui keefektifan dari produk terhadap perkembangan anak usia dini. Teknik analisis data dilakukan untuk mencari kevalidan dan keefektifan dari electronic wordless picture book dengan menggunakan statistika deskriptif.

Analisis data kevalidan menggunakan acuan kriteria dari Widyoko (2013) sebagaimana pada tabel 1. Sedangkan analisis data keefektifan menggunakan rumus 1.

Tabel 1. Acuan Konversi Data Kuantitatif menjadi Data Kualitatif 


\begin{tabular}{|c|c|c|}
\hline No. & Interval Skor & Klasifikasi \\
\hline 1 & $\bar{x}>M_{i}+1,8 S b_{i}$ & Sangat Baik \\
\hline 2 & $M_{i}+0,6 S b_{i}<\bar{x} \leq M_{i}+1,8 S b_{i}$ & Baik \\
\hline 3 & $M_{i}-0,6 S b_{i}<\bar{x} \leq M_{i}+0,6 S b_{i}$ & Cukup \\
\hline 4 & $M_{i}-1,8 S b_{i}<\bar{x} \leq M_{i}-0,6 S b_{i}$ & Kurang \\
\hline 5 & $\bar{x}<M_{i}-1,8 S b_{i}$ & Sangat Kurang \\
\hline
\end{tabular}

Keterangan : $\mathrm{P}=$ nilai akhir, $\sum \mathrm{R}=$ jumlah skor hasil penilaian, dan $\mathrm{N}=$ jumlah skor maksimal

\section{HASIL DAN PEMBAHASAN}

Penelitian pengembangan ini menghasilkan produk berupa electronic wordless picture book untuk mengenalkan social justice pada anak usia 4-6 tahun. Penelitian pengembangan ini menggunakan model ADDIE (analyze, design, development, implementation, evaluation).

\section{Tahap Analisis}

Pada tahap ini, peneliti melakukan analisis kebutuhan berupa analisis keadaan lapangan dan anak serta pengumpulan referensi materi yang akan dituangkan di dalam buku cerita elektronik. Kegiatan analisis lapangan dilakukan melalui pengumpulan informasi kondisi pembelajaran di RA Muslimat NU Darunnajah melalui observasi dan wawancara. Observasi dilakukan selama 2 hari, sedangkan wawancara dilakukan 1 hari dengan 2 orang guru sebagai sumber datanya. Materi tentang keadilan sosial penting diberikan kepada anak usia dini di RA Darun Najah berdasarkan hasil wawancara sebagai berikut.

"Mengajarkan keadilan sosial itu biasanya sebatas konteks sehari-hari, belum menggunakan media. Misalnya ketika bermain ada yang membeda-bedakan teman atau ada yang berkelahi karena berebut mainan" (ND, 23 tahun).

Selain itu, salah satu guru menjelaskan bahwa untuk kasus bullying jarang sekali terjadi, tetapi untuk kasus kesetaraan gender kerap kali terjadi di sekolah ini bahkan sering. Hal ini dibuktikan dari hasil wawancara berikut ini.

"Pernah, dan anak tersebut tidak membolehkan anak laki-laki untuk bermain mandi bola bersama anak perempuan, dan anak laki-laki hanya diperbolehkan main permainan outdoor. Hal itu sudah ditangani oleh para ustadzah dengan memberikan pengertian kepada anak perempuan tersebut, bahwa semua permainan yang ada di sekolah boleh dimainkan oleh semua anak baik dari gender laki-laki maupun perempuan" (BS, 24 tahun)

Adapun hasil dari analisis kebutuhan ini didapat disimpulkan bahwa: (a) materi tentang keadilan sosial (social justice) masih jarang disampaikan oleh guru, (b) beragamnya latar belakang anak didik dari segi sosial dan ekonomi menjadi kebutuhan untuk disampaikan materi tentang keadilan sosial (social justice), (c) belum ada media buku cerita elektronik yang digunakan guru di dalam pembelajaran, (d) terdapat sarana dan prasarana berupa LCD, proyektor, sound, dan laptop sehingga mendukung digunakannya buku cerita elektronik, serta (e) 5 dari 6 guru masih berusia muda dan lulusan PG-PAUD sehingga mendukung diterapkannya media pembelajaran berbasis teknologi.

\section{Tahap Desain}


Pada tahap desain, peneliti merancang Electronic Wordless Picture Book yang berfokus pada pengenalan social justice yang meliputi narasi cerita, referensi, pembuatan garis-garis besar, dan story board. Selain itu, peneliti juga menyusun instrumen untuk validasi media dan materi, serta instrumen uji coba media untuk anak dan untuk guru. Adapun langkah-langkah dalam mendesain media buku elektronik adalah sebagai berikut: (a) menentukan pengetahuan dan sikap yang akan didapat anak, setelah menggunakan buku cerita elektronik, dimana anak akan lebih memahami tentang keadilan sosial yang terdiri dari mengenal perasaan sendiri dan mengelola secara wajar, menghargai keunggulan atau pendapat orang lain, mengetahui akan haknya, menunjukkan rasa empati, menunjukkan sikap toleran, dan menggunakan cara yang diterima secara sosial dalam menyelesaikan masalah, (b) mendesain tokoh dan karakter, menentukan berapa tokoh yang akan terlibat dalam Electronic Wordless Picture Book serta menentukan karakternya sehingga akan tercapai desain tokoh yang sesuai, (c) pembuatan storyboard yang merupakan deskripsi gambaran dalam pembuatan media pembelajaran untuk memudahkan proses pembuatan sebuah produk, (d) penyusunan narasi dimana harus menyesuaikan dengan materi yang akan disampaikan di tiap halaman storyboard lalu dibuat audio, dan (e) penyusunan instrumen validasi dalam bentuk angket yang ditujukan kepada ahli materi dan ahli media dengan menggunakan skala penilaian 1-5.

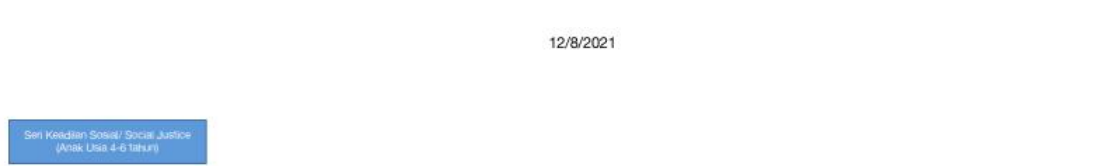

Aku sayang semua teman

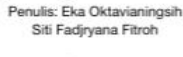

thentor

Aku sayang semua teman

- Tokoh

- Petunjuk Pemakaian Buku

Cerita 1: Semuanya Teman

- Cerita 2: Bolehkah Aku Main Apa Saja?

- Pembelajaran yang dapat dipetik

- Tips menanamkan keadilan sosial untuk anak

- Profil Penulis

\section{Gambar 2. Cuplikan Rancangan Narasi Cerita}

\section{Tahap Pengembangan}

\section{Pembuatan Media Pembelajaran}

Tahapan pembuatan buku cerita elektronik dimulai dengan membuat gambar sesuai dengan cerita menggunakan laptop/komputer kemudian disimpan dalam bentuk png atau .jpg. Dalam waktu bersamaan, dibuat juga audio yang akan digunakan dalam penyampaian cerita. Kemudian semua unsur-unsur media tersebut dirangkai semua menggunakan software Flip Builder sesuai dengan story board yang telah dirancang sebelumnya. Adapun isi dari buku cerita elektronik ini terdiri dari 2 cerita. Isi lengkap dari buku cerita elektronik tersaji dalam Tabel 2 dan cuplikan electronic wordless picture book pada gamabr 3. 
Tabel 2. Isi/Konten Electronic Wordless Picture Book

\begin{tabular}{|c|c|c|}
\hline No. & Susunan & Keterangan \\
\hline 1. & Sampul & $\begin{array}{l}\text { Judul: Aku Sayang Semua Teman } \\
\text { Gambar disesuaikan dengan tema social justice di Taman kanak- } \\
\text { kanak }\end{array}$ \\
\hline 2. & Isi & $\begin{array}{ll}\checkmark & \text { Daftar Isi } \\
\checkmark & \text { Pengenalan Tokoh } \\
\checkmark & \text { Pentunjuk Pemakaian Buku } \\
\checkmark & \text { Cerita 1: Semuanya Teman } \\
\checkmark & \text { Cerita 2: Bolehkah Aku Main Apa Saja? }\end{array}$ \\
\hline 3. & Penutup & $\begin{array}{ll}\checkmark & \text { Pembelajaran yang bisa dipetik dari cerita } \\
\checkmark & \text { Tips mengajarkan nilai keadilan sosial kepada anak } \\
\checkmark & \text { Tentang Penulis }\end{array}$ \\
\hline
\end{tabular}

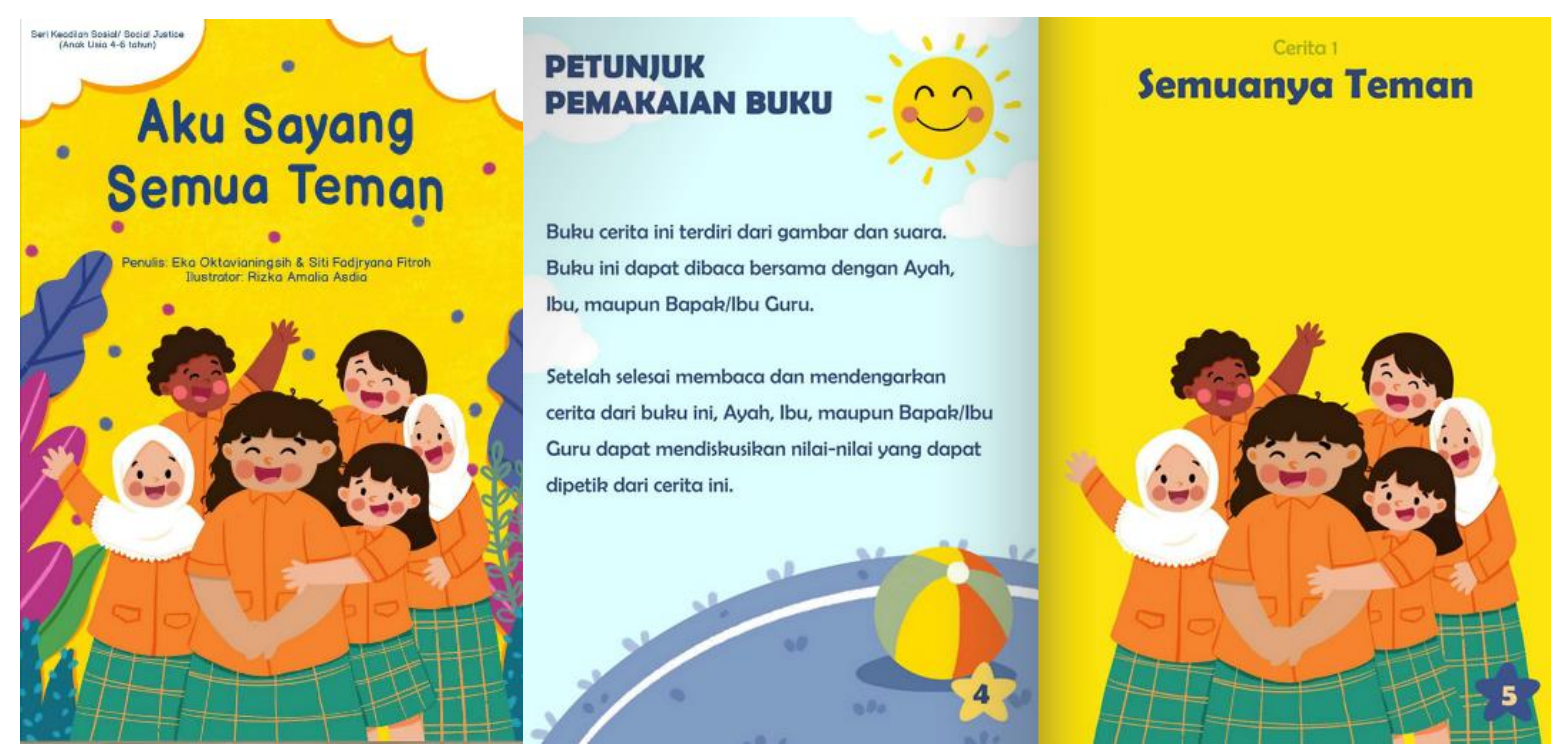

Gambar 3. Cuplikan Electronic Wordless Picture Book

\section{Validasi Media Pembelajaran}

Media buku cerita elektronik divalidasi dari segi materi dan segi media. Segi materi, media buku elektronik divalidasi oleh Erma Kusumawardani (Dosen Pendidikan Luar Sekolah Universitas Negeri Yogyakarta) dengan hasil skor 34 dengan kriteria "Sangat Baik" sedangkan dari segi media divalidasi oleh Naili Sa'ida (Dosen PG-PAUD Universitas Muhammadiyah Surabaya) dengan hasil skor 45 dengan kriteria "Sangat Baik". Adapun kedua validator memberikan saran perbaikan, diantaranya: (1) dari ahli media: ditambahkan nomor halaman, warna gambar dicerahkan sedikit, ada daftar isi, dan (2) dari ahli materi: pada cerita kedua lebih diperjelas nilai yang ingin disampaikan.

Kriteria yang digunakan dalam validasi media pembelajararan tersebut mengacu pada pendapat Widyoko (2013) yang tercantum dalam tabel 3 dan tabel 4.

Tabel 3. Acuan Kriteria Penilaian Ahli Materi

\begin{tabular}{lcc}
\hline No. & Interval Skor & Klasifikasi \\
\hline 1 & $X>33.6$ & Sangat Baik \\
2 & $33,6>X>27,2$ & Baik \\
3 & $27,2>X>20,8$ & Cukup \\
4 & $20,8>X>14,4$ & Kurang \\
5 & $X<14,4$ & Sangat Kurang \\
\hline
\end{tabular}


Tabel 4. Acuan Kriteria Penilaian Ahli Media

\begin{tabular}{lcc}
\hline No. & Interval Skor & Klasifikasi \\
\hline 1 & $X>42$ & Sangat Baik \\
2 & $42>X>34$ & Baik \\
3 & $34>X>26$ & Cukup \\
4 & $26>X>34$ & Kurang \\
5 & $X<18$ & Sangat Kurang \\
\hline
\end{tabular}

Berdasarkan hasil validasi tersebut, maka dapat disimpulkan bahwa Electronic Wordless Picture Book untuk mengenalkan social justice pada anak usia 4-6 tahun yang telah dikembangkan dinilai layak untuk diuji cobakan kepada anak-anak usia 4-6 tahun.

\section{Tahap Implementasi}

Pada tahap ini, dilakukan implementasi atau penerapan produk yang sudah dikembangkan terhadap 30 anak usia 4 sampai 6 tahun di KB/TK Muslimat NU Darunnajah, Kamal, Bangkalan. Adapun desain yang digunakan dalam tahapan ini adalah model one shot case study, dimana dalam penelitian ini tidak ada kelompok kontrol dan anak diberikan perlakuan khusus selama beberapa waktu. Subjek dalam penelitian ini akan mendapatkan perlakuan yaitu berupa Electronic Wordless Picture Book. Di akhir program, anak akan diamati/diobservasi terkait indikator social justice. Adapun desain uji coba pada penelitian ini dapat dilihat pada tabel 5 .

Tabel 5. Desain one shot case study

\begin{tabular}{|c|c|c|}
\hline Subjek & Treatment & Observasi \\
\hline 1 kelompok (30 anak) & $\mathrm{X}$ & $\mathrm{O}$ \\
\hline
\end{tabular}

Adapun total skor diperoleh dari 6 indikator antara lain: (a) mengenal perasaan sendiri dan mengelolanya secara wajar, (b) menghargai keunggulan/pendapat oranglain, (c) mengetahui akan haknya, (d) menunjukkan rasa empati, (e) menunjukkan sikap toleran, dan (f) menggunakan cara yang diterima secara sosial dalam menyelesaikan masalah. Masingmasing indikator memiliki skor 1 sampai dengan 4, sehingga total skor maksimal untuk 6 indikator adalah 24, sedangkan untuk minimal total skor adalah 6 . Hasil dari observasi diperoleh skor tentang kemampuan anak dalam hal keadilan sosial yang ditampilkan pada Tabel 6.

Tahap ini dilakukan untuk mengetahui keefektifan produk yang telah dikembangkan. Adapun hasil dari uji efektivitas dapat dilihat pada grafik 1 . Hasil perhitungan uji efektivitas yang dikumpulkan melalui lembar observasi/pengamatan terhadap kemampuan social justice anak menunjukkan skor $82.917 \%$ dengan kriteria baik. Dari hasil uji efektivitas tersebut dapat disimpulkan bahwa bahwa Electronic Wordless Picture Book yang dikembangkan sangat efektif dalam mengenalkan social justice pada anak usia 4 sampai 6 tahun.

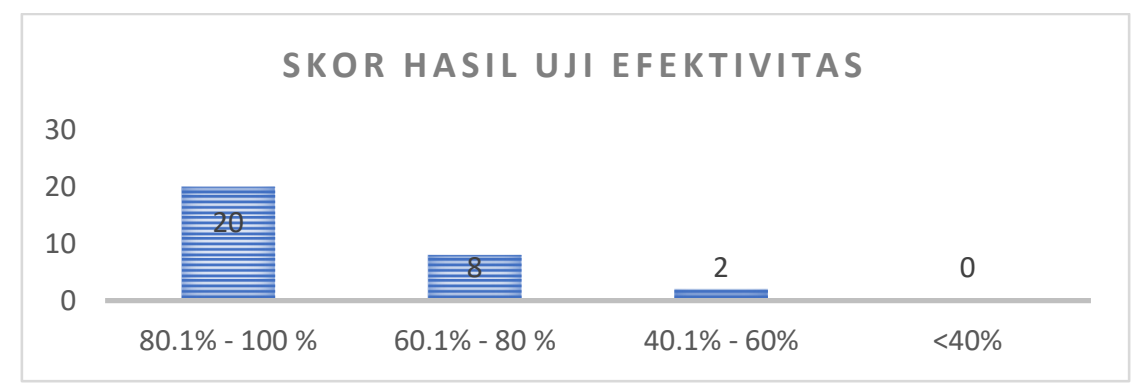

Grafik 1. Skor Hasil Uji Efektivitas 
Pengembangan Electronic Wordless Picture Book untuk Mengenalkan Social Justice pada Anak Usia 4-6 Tahun DOI: $10.31004 /$ obsesi.v6i4.1992

Tabel 6. Akumulasi Skor Hasil Observasi Social Justice Anak Usia 4-6 Tahun

\begin{tabular}{|c|c|c|c|c|c|c|c|}
\hline No & Kode Subjek & $\begin{array}{l}\text { Total } \\
\text { Skor }\end{array}$ & Persentase & No & Kode Subjek & $\begin{array}{l}\text { Total } \\
\text { Skor }\end{array}$ & Persentase \\
\hline 1 & ALF & 19 & 79,16666667 & 16 & ASYH & 21 & 87,5 \\
\hline 2 & $\mathrm{RF}$ & 12 & 50 & 17 & ULF & 21 & 87,5 \\
\hline 3 & $\mathrm{BM}$ & 20 & 83,33333333 & 18 & $\mathrm{AF}$ & 20 & 83,33333333 \\
\hline 4 & $\mathrm{DM}$ & 22 & 91,66666667 & 19 & $\mathrm{AL}$ & 24 & 100 \\
\hline 5 & FRL & 20 & 83,33333333 & 20 & $\mathrm{OM}$ & 15 & 62,5 \\
\hline 6 & AYG & 21 & 87,5 & 21 & ALFN & 17 & 70,83333333 \\
\hline 7 & LBN & 14 & 58,33333333 & 22 & $\mathrm{RR}$ & 22 & 91,66666667 \\
\hline 8 & ADN & 18 & 75 & 23 & NL & 18 & 75 \\
\hline 9 & HDR & 20 & 83,33333333 & 24 & FN & 24 & 100 \\
\hline 10 & ATF & 20 & 83,33333333 & 25 & MRY & 24 & 100 \\
\hline 11 & AZM & 19 & 79,16666667 & 26 & NI & 18 & 75 \\
\hline 12 & MKL & 22 & 91,66666667 & 27 & NR & 20 & 83,333333333 \\
\hline 13 & ATN & 22 & 91,66666667 & 28 & LTF & 19 & 79,16666667 \\
\hline 14 & ARF & 21 & 87,5 & 29 & RBT & 20 & 83,333333333 \\
\hline 15 & $\mathrm{AN}$ & 21 & 87,5 & 30 & NY & 23 & 95,83333333 \\
\hline
\end{tabular}

$$
\begin{gathered}
P=\frac{597}{30 \times 24} \times 100 \% \\
P=\frac{597}{720} \times 100 \% \\
P=82.917 \%
\end{gathered}
$$

\section{Tahap Evaluasi}

Pada tahap ini akan dilakukan analisis data validasi media pembelajaran dari ahli media dan ahli materi. Selain itu, dilakukan analisis data terkait hasil observasi anak dan angket respon guru. Pada tahap ini juga diperoleh produk akhir berupa Electronic Wordless Picture Book untuk Mengenalkan Social Justice pada Anak Usia 4-6 Tahun".

Penelitian pengembangan ini menghasilkan produk akhir berupa Electronic Wordless Picture Book untuk anak usia 4-6 tahun dalam mengenalkan nilai-nilai keadilan sosial. Produk ini dapat dijadikan salah satu media pembelajaran yang digunakan guru dalam mengajarkan nilai-nilai keadilan sosial kepada anak usia dini secara menarik dan menyenangkan. Anak akan lebih memahami tentang keadilan sosial yang terdiri dari mengenal perasaan sendiri dan mengelola secara wajar, menghargai keunggulan atau pendapat orang lain, mengetahui akan haknya, menunjukkan rasa empati, menunjukkan sikap toleran, dan menggunakan cara yang diterima secara sosial dalam menyelesaikan masalah.

Dalam proses pengembangannya, peneliti telah melakukan analisis kebutuhan mengapa produk dianggap penting untuk dikembangkan. Pertama, materi tentang keadilan sosial pada anak masih jarang disampaikan guru di kelas. Guru masih menganggap bahwa mengajarkan social justice pada anak merupakan usaha yang terlalu dini (Solehuddin, \& Adriany, 2017). Lynch (2019) dalam penelitiannya juga mengungkapkan bahwa social justice atau keadilan sosial dapat diajarkan kepada anak-anak melalui berbagai cara diantaranya melalui cerita dengan materi perbedaan/keberagaman, gender, maupun ras. Belum adanya media buku cerita elektronik yang digunakan guru juga menjadi penyebab lain mengapa produk perlu dikembangkan. Selama ini buku cerita masih banyak dikemas dalam bentuk cetak, padahal buku cerita dengan bentuk elektronik juga efektif apabila sudah sesuai materi yang ingin disampaikan. Hal ini sesuai dengan penelitian Wahyu \& Khusnul (2018) yang mengungkapkan bahwa peserta didik akan termotivasi dan tertarik terhadap materi yang disampaikan sehingga membantu guru dalam mengatasi masalah pembelajaran di kelas dan sesuai tujuan pembelajaran yang sudah ditetapkan 
Electronic Wordless Picture Book dikembangkan oleh peneliti agar guru maupun orangtua dapat melibatkan media tersebut untuk mengenalkan social justice kepada anak usia dini, khususnya pada anti bullying dan kesetaraan gender. Penelitian sebelumnya telah dilakukan oleh Ningrum (2021) terkait pencegahan bullying pada anak usia dini dengan mengembangkan buku panduan anti bullying yang dapat digunakan oleh guru di sekolah. Selain itu, Electronic Wordless Picture Book ini dapat menarik dan memotivasi anak untuk bercerita dengan sendiri, membentuk persepsi sendiri. Sesuai dengan penelitian Yu (2012) yang menyatakan bahwa anak-anak usia 3-5 tahun dicirikan dengan ketergantungan pada persepsi mereka karena mereka melihat apa yang tampak pada mereka melalui gambargambar. Selain itu, dalam penelitian Rizqiyani (2018) menyatakan bahwa Wordless Picture Book juga efektif untuk meningkatkan kemampuan bercerita pada anak prasekolah dibandingkan buku cerita pada umunya, anak lebih mahir dalam memilih kata dan gesture melalui gambar yang dilihat.

Hasil validasi menunjukkan bahwa Electronic Wordless Picture Book yang dikembangkan mendapatkan kategori "sangat baik" sehingga layak untuk diujicobakan kepada anak usia 4-6 tahun. Sebuah produk dikatakan valid karena telah memenuhi uji validitas oleh ahli media maupun ahli materi. Ujicoba yang telah dilakukan terhadap 30 anak usia 4-6 tahun menunjukkan bahwa media yang dikembangkan telah efektif untuk mengenalkan social justice pada anak. Dengan demikian, secara keseluruhan produk media pembelajaran Electronic Wordless Picture Book yang dikembangkan telah memenuhi kriteria valid dan efektif untuk digunakan guru maupun orangtua dalam mengenalkan keadilan sosial khususnya sikap anti bullying dan kesetaraan gender pada anak usia dini.

\section{SIMPULAN}

Berdasarkan hasil penelitian dan pembahasan, maka dapat disimpulkan bahwa: (1) electronic wordless picture book dikembangkan karena keterbatasan materi dan media tentang keadilan sosial (social justice) pada anak usia 4-6 tahun dan (2) electronic wordless picture book telah layak digunakan untuk mengenalkan social justice pada anak usia 4-6 tahun karena telah valid dan efektif. Dikarenakan pentingnya pengenalan social justice sejak usia dini, media ini diharapkan dapat diperkaya dengan materi social justice yang lainnya selain anti bullying dan kesetaraan gender. Selain itu, media ini juga diharapkan dapat dipublikasikan lebih luas lagi karena bersifat elektronik.

\section{UCAPAN TERIMA KASIH}

Penulis mengucapkan terimkasih kepada Universitas Trunojoyo Madura yang telah memberikan kesempatan kepada penulis dan kepada RA NU Muslimat Darunnajah yang telah bersedia menjadi responden dalam penelitian ini.

\section{DAFTAR PUSTAKA}

Burman, E. (2017). Deconstructing developmental psychology. New York: Routledge. https:// doi.org/10.4324/9781315727127

Ciampa, K. (2012). Electronic storybooks: A constructivist approach to improving reading motivation in grade 1 students. Canadian Journal of Education, 35(4), 92-136.

Ciecierski, L., Nageldinger, J., , Blintz, W. P., , \& Moore, S. D. (2017). New Perpective on Picture Books. Athens Journal of Education, 123-136.

https:// doi.org/10.30958/aje.4-2-2

Darihastining, S., Aini, S.N., , Maisaroh, S., , \& Mayasari, D. (2021). Penggunaan media audio visual berbasis kearifan budaya lokal pada anak usia dini. Jurnal Obsesi, Volumr 5, Issue 2. https:// doi.org/10.31004/obsesi.v5i2.923

Evans, M. A., Nowak, S., Burek, B., \& Willoughby, D. (2017). The effect of alphabet eBooks and paper books on preschoolers' behavior: An analysis over repeated readings. Early 
Childhood Research Quarterly, 40(September), 1-12. https://doi.org/10.1016/j.ecresq.2017.02.002

Fithriyana, R. (2017). Hubungan Bullying Dengan Lingkungan Sosial Ekonomi dan Prestasi Pada Siswa SDN 006 Langgini. Jurnal Basicedu 1(1), 89-96. https://doi.org/10.31004/basicedu.v1i1.161

Giraldo, E. (2008). Uncovering Gender Relations and Interactions Promoted by Early Childhood Curricula. Disertation. ProQuest. UMI Microform: Ann Arbor.

Hawkins, K. (2006). Teaching for social justice: A pedagogy for Twenty-first Century early childhood education. Elenes, 1-16.

Isik, M. (2016). The Impact of Storytelling on Young Ages. European Journal of Language and Literature 6(1), 115. https://doi.org/10.26417/ejls.v6i1.p115-118

Jalongo, M. R., Dragich, D., Conrad, N. K., \& Zhang, A. (2002). Using wordless picture books to support emergent literacy. Early Childhood Education Journal, 29(3), 167-177. https://doi.org/10.1023/A:1014584509011

Lynch, M. (2019). Teaching social justice in your classroom. Retrieved from https://www.theedadvocate.org/teaching-social-justice-in-your-classroom/

Ningrum, M., \& Wardhani, A.M.R.K. (2021). Pengembangan Buku Panduan Anti-Bullying untuk Mengembangkan Keterampilan Sosial Emosional Anak Usia Dini. Golden Age: Jurnal Ilmiah Tumbuh Kembang Anak Usia Dini, Vol. 6(3), 131-142. https://doi.org/10.14421/jga.2021.63-03

Nurhasanah, N., Nadiroh,, \& Nafiah, M. (2019). Developed Students Character at Elementary School through Wordless Picture Book. Advances in Social Science. Education and Humanities Research, 335, 12-17. https:// doi.org/10.2991/icesshum-19.2019.3

Purnamasari, Y. (2019). Media pembelajaran big book berbasis cerita rakyat untuk meningkatkan karakter toleransi pada anak usia dini. Jurnal Obsesi, Volume 4, No 1. hal 90-99. https:/ / doi.org/10.31004/obsesi.v4i1.273

Putri, D. (2016). Media Anti Bullying: Pembimbingan Anak Usia Dini pada Taman Kanakkanak di Kota Singaraja. Vol 5, No 1, bulan januari, 1410-4369. https://doi.org/10.23887/jwl.v5i1.9101

Rizqiyani, R., \& Nur, A. (2018). Kemampuan Bercerita Anak Prasekolah (5-6 Tahun). Jurnal Pendidikan Anak Vol 7(2), 146-155. https://doi.org/10.21831/jpa.v7i2.24458

Santrock, J. (2014). Psikologi Pendidikan. Jakarta: Kencana.

Seidel, J., \& Rokne, A. (2011). Picture Books for Engaging Peace and Social Justice With Children. Diaspora, Indigenous, and Minority Education, 5(4), 245-259. https:// doi.org/10.1080/15595692.2011.606007

Solehuddin, M. \&. (2017). Kindergarten teachers' understanding on social justice: stories from Indonesia. SAGE Open, 7(4). https:// doi.org/10.1177/2158244017739340

Solehuddin, M., \& Adriany, V. (2017). Kindergarten teachers understanding on social justice: stories from indonesia. SAGE Open. https:// doi.org/10.1177/2158244017739340

Widyoko, E. (2013). Teknik Penyusunan Instrumen Penelitian. Yogyakarta: Pustaka Pelajar.

Young, I. M. (2011). Justice and the Politics of Difference. NJ: Princeton University Press.

Yu, X. (2012). Exploring Visual Perception and Children's Interpretations of Picture Books. Library \& Information Science Research, 34(4), 292-299. https://doi.org/10.1016/j.lisr.2012.06.004

Zakiyah, E., Humaedi, S., \& Santoso, M.B. (2017). Faktor yang mempengaruhi remaja dalam melakukan bullying. Jurnal Penelitian \& PPM. Volume 4, No.2, 129-389. https://doi.org/10.24198/jppm.v4i2.14352 